\title{
THE EfFECT Of MANAgEMENT CONTROL SYSTEMS ON Employee Performance: Communication SKILl as a MOdERATING VARIABLE
}

\author{
Muhammad Dahlan
}

Department of Accounting,

The University of Padjadjaran, Bandung 40132,

Indonesia

dahlanm2004@yahoo.com

*Corresponding Author email: dahlanm2004@yahoo.com

Submission: 20 November 2020 Revised: 24 December $2020 \quad$ Accepted: 19 January 2021

Peer-review under responsibility of 6th Asia International Conference 2020 (Online) Scientific Committee http://connectingasia.org/scientific-committee/ (C) 2021 Published by Readers Insight Publisher, Office \# 6, First Floor, A \& K Plaza, Near D Watson, F-70 Markaz, Islamabad. Pakistan, editor@readersinsight.net This is an open access article under the CC BY license (http://creativecommons.org/licenses/4.0/). 


\section{A B S T R A C T}

This study examines the effect of management control systems (MCS) on performance, communication skill as a moderating variable. We had distributed questionnaire to collect data of 42 institution of public services, that are population were draw in West Java, Indonesia period of June November, 2019. The names of 140 middle-level managers random was used their perception what cause and effect strategic use of management control systems implementation to subordinate level and their employees working departmental and that gained of 71 usable responses for final data. The analysis indicated that MCS namely are diagnostic control and interactive control has a direct and positively effect on employee performance, and that communication skill has a moderate effect on the relationship between diagnostic control system and performance. Interactive control did not as a moderating variable, still on that interacting have been extent to which of intensively communicate in the organizational context, but diagnostic control namely periodically to communicate between top management and subordinate level. We also find that use of MCS package, while employees themselves participate in their own departmental performance measures will improve performance were put to use. The West Java Institution is join approach of strategic use between DCS and ICS for subordinate level, that are encourages for employee motivations and performance.

Keywords: Management Control Systems, Diagnostic Control, Interactive Control, Communication Skill, Employee Performance

\section{R E S E ARC H H I G H L I G T S}

The contingency context of MCS literature that managers pay attentions to adapt their policy would likely has been adjusted affect by environmental changes in organizations that complementary set up to fit and performed (Abernethy and Brownell, 1997; Chenhall, 2003 and Fisher, 1998). The MCS's in public sector, for example, Well-timed, Zhang (2014) introduce a model for public institutions not only for profit motives but too non-profit organizations. Henceforth, this concepts would interested in the MCS study, new ideas and critical view the elements in the management control process for government organizations. Chowdhury and Shil (2016) the new perspective of innovative in MCS and then importance on New Public Management (NPM) context initiatives were interested. It is argued that adopted various management control tools to improve performance and accountability. It appears from that these adopted of management control tools would be forced some organization towards better performance. Hence, that has stated, MCS's could be implied in the government organizations.

\section{G R A P I C A L A B S T R A C T}

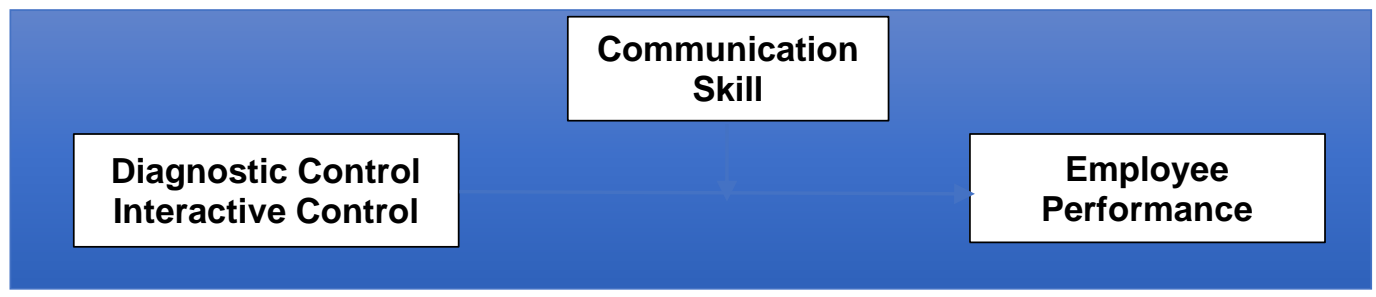

Research Model 


\section{The Research Formulations and Regression Results:}

\section{Diagnostice control $\rightarrow$ Employee Performance}

1.1. E-Perfom $=C+\beta 1$ Diagnos $+e$

1.2. E-Perfom $=C+\beta 1$ Diagnos $+\beta 2$ Comm $+e$

1.3. E-Perfom $=C+\beta 1$ Diagnos $+\beta 2$ Comm $+\beta 3$ Diagnos $\times$ Comm $+e$

\begin{tabular}{llllll}
\hline Model $^{\mathbf{a}}$ & Value & SE & $\boldsymbol{\beta}$ & $\mathbf{t}$ & Sig \\
\hline (Constant) $_{\text {Diagnostice_Control }}$ & 15.448 & 2.288 & & 6.752 & .000 \\
\hline Constant) $_{\text {Diagnostice_Control }}$ & .710 & .108 & .622 & 6.598 & .000 \\
\hline Communication_Skills & 8.999 & 2.628 & & 3.424 & .001 \\
\hline Constant) $_{\text {Diagnostice_Control }}^{.535}$ & .107 & .469 & 5.013 & .000 \\
Communication_Skills & .488 & .122 & .374 & 3.996 & .000 \\
Moderating_DiagnosticexComm & -17.774 & 13.484 & & -1.318 & .192 \\
\hline
\end{tabular}

Dependent Variable: Employee_Performence

\section{Interactive control $\rightarrow$ Employee Performance}

2.1. E-Perfom $=C+\beta 1$ Interact $+e$

2.2. E-Perfom $=C+\beta 1$ Interact $+\beta 2$ Comm $+e$

2.3. E-Perfom $=C+\beta 1$ Interact $+\beta 2$ Comm $+\beta 3$ Diagnos $\times$ Comm $+e$

\begin{tabular}{llllll}
\hline Model $^{\mathbf{a}}$ & Value & SE & $\boldsymbol{\beta}$ & $\mathbf{t}$ & Sig \\
\hline (Constant) $_{\text {Interactive_Control }}$ & 14.621 & 2.295 & & 6.370 & .000 \\
\hline (Constant) & .947 & .137 & .641 & 6.937 & .000 \\
Interactive_Control & 9.181 & 2.606 & & 3.523 & .001 \\
Communication_Skills & .714 & .142 & .483 & 5.036 & .000 \\
\hline Constant) $_{\text {Interactive_Control }}$ & .450 & .125 & .344 & 3.589 & .001 \\
Communication_Skills & -5.384 & 13.080 & & -.412 & .682 \\
Moderating_InteractivexComm & 1.573 & .769 & 1.064 & 2.046 & .045 \\
\hline
\end{tabular}

\section{Research Objectives}

MCS must be aligned with an organization's structure and closely aligned with the organization's strategies and goals (Horngren, et al., 2015). For example, government organizations in order look like of an organization with decentralized. The next study I thing a good research in area of service organizations and non-profit motive but this area a little interest show there are most urgent to be confirmatory that is MCS implementation (Chenhall, 2003).

Leadership communication and employee communication intensive may some patter for elaborate that the condition of uncertainty pay consider for recovery job satisfaction and subordinate performance (Nguyen, et al., 2017; Abernethy, et al. 2010; Dekker, 2004; and Crespo, et al., 2019). Hence, employee participation, communication channel, and 
organization commitment has been to help ensure that the achievement of their goals or their performance (Pettit, et al., 1997; Erben, et al., 2019; Atouba, et al., 2019; and Smith, et al., 2018). However, managers will be much initiative and better match between the control systems and the contextual or contingency variable in order toward result were increased organization (individual) performance (Fisher, 1998; Chenhall, 2003; and Henry, 2006).

The perceived of communication skill might be proposed one model for manager that will generate and matching on between the MCS designing and organization contingency, thus that is in order toward increase performance. Previous researcher has done, link and match between task of communication skill aspect and MCS's design (Nguyen, et al., 2017; Vaio, et al., 2019; Kelvin-Iloafu, 2016; Luft, 2016; Beuren and Teixeira, 2014). That is beneficiary of organization communication and leadership characteristic will importance as a reach employee's participation would lead performance (Abernethy, et al,2010).

Therefore, link and match task of communication in the relationship between strategic use of management control systems and employee performance as a research focus, namely is task of communication skill as a moderator between diagnostic control \& interactive control and employee performance. So, if good fit is a greaten of individual performance and bad fit is a reduce individual performance.

\section{Methodology}

\section{Sample Selection.}

A total of 42 institution of public services, that are population were draw from public service in West Java, Indonesia, as a 140 lower management level was used. Each respondent candidates were sent questionnaire package on cover letter stamp post complete and return envelope. Yield of 115 participants, a total of 83 questionnaires on November 2019 a response rate of 72 percent and 71 usable responses for final data and analysis to test the hypothesis. in this study we used five-point Likert-type scale ranges from 1 (strongly disagree) and to 5 (strongly agree). Validity and reliability testing was adopted by Chenhall and Langfield-Smith (1998) and Nunnally and Bernstein (1994).

\section{Measurement of Variables.}

Strategic use of management control systems. We adopt by Simon's $(1995,2014)$ nine-item, including of five items for diagnostic control systems and four items for interactive control systems. Communication skills. Berman and Hellweg (1989) individual concerned including the elements of knowledge, motivation, skills, behaviour, and effectiveness. Employee performance. Burney, et al (2009) employee performance is a task performance, that are seven items performance measurement. The performance was measured by self-rated from managers perceive to subordinates level and characteristics of the SPMS has associated with perceived organizational fairness. 


\section{Results}

Descriptive and variables interrelationship, shows that, the inter-correlations among the all measured variables were all revealed that was positively correlated, that all significant at the 0.01 level. Therefore, the most suitable pattern of employee performance, diagnostic control system, interactive control system, and communication skill variable in this research. Additional judgment, the all mean score over the standard deviation, that look like an acceptable of measured variable were all single dimensions.

Validity and reliability testing shows that, the lower of loading factor is 0.626 and or above. That all variables and indicators validity were all at an acceptable level 0.424 or above (Chenhall and Langfield-Smith, 1998). Then, internal reliability test for Cronbach alpha coefficients that all measured variables was an acceptable level 0.60 or above (Nunnally and Bernstein, 1994). However, initial eigenvalues for all the measured variables of $54.944 \%$ or above, that is look like the single-loading factor.

Then, F-test in figure above, our concluded that communication skill was proceed in the relationship between management control systems and performance, the moderating variable, but based on t-test shows that, only diagnostic control systems positive effect on employee performance, while communication skill as a moderating variable.

\section{Findings}

MCS design that is extent to which of more intensive explore of strategic priorities in management policy will important for improve goal congruence (Chenhall, 2003 and Simons, 2014). Then, MCS study will be pro-active to be on environmental uncertainty, that are closely on contingency factors show that the assuming managers has approached to adjusted policy but pay attention the strategic outcome an intent to adapt in their organizations will be to fit and performed (Chenhall, 2003 and Simons, 2014). Leader and Employee participation in communication and generating of organization communicates pay more intention it is increase to fit relationship between contingency of using MCS design and performance (Simons, 2014; Abernethy, et al, 2010 and Langfield-Smith, 1997).

This study might be confirmatory conceptual of the contingency factor in management accounting, because only diagnostic control systems positively effect and significant on employee performance, while a communication skill have been proved as a moderating variable. Simple statement, good fitting MCS design and communication style will be improved performance, and/or poor fitting MCS design and communication style will be reduce performance.

\section{Acknowledgement}

Thank you for the Directorate of Research and Development, Minestery of Research, Technology and Higher Education RI as a research funder, cooperation with the University of Padjadjaran, Indonesia year of 2019. 


\section{References}

Abernethy, M. A. and Brownell, P. (1997). Management control systems in research and development organizations: the role of accounting, behaviour and personnel controls. Accounting, Organizations and Society, 22 (3-4): 233 - 248. https://doi.org/10.1016/S0361-3682(96)00038-4

Abernethy, M. A, Bouwens, J. and Lent, L. (2010). Leadership and control system design. Management Accounting Research, $21 \quad$ (1): 2 - 16. https://doi.org/10.1016/j.mar.2009.10.002

Atouba, Y. C., Elizabeth J. Carlson, E. J., and John C. Lammers, J. C. (2019). Directives and dialogue: examining the relationship between participative organizational communication practices and organizational identification among IT workers. International Journal of Business Communication, 56 (4): 530 - 559. https://doi.org/10.1177/2329488416672430

Berman, S. J. and Hellweg, S. A. (1989). Perceived supervisor communication competence and supervisor satisfaction as a function of quality circle participation. International Journal of Business Communication, 26 (2): 103-122. https://doi.org/10.1177/002194368902600202

Beuren, I. M and Teixeira, S. A. (2014). Evaluation of management control systems in a higher education institution with the performance management and control. Journal of Information Systems and Technology Management, 11 (1): 169 - 192. https://doi.org/10.4301/S1807-17752014000100010

Burney, L.L., Henle, C.A., Widener, S.K. (2009). A path model examining the relations among strategic performance measurement system characteristics, organizational justice, and extra- and in-role performance. Accounting, Organizations and Society, 34 (34), 305-321. https://doi.org/10.1016/j.aos.2008.11.002

Chenhall, R. H. (2003). Management control systems design within its organizational context: findings from contingebcy-based research and direction for the future. Accounting, Organizations and Society, 28 (2-3): 127 - 168. https://doi.org/10.1016/S0361-3682(01)00027-7

Chenhall, R. H. and Langfield-Smith, K. (1998). The relationship between strategic priorities, management techniques and management accounting: an empirical investigation using a systems approach. Accounting, Organizations and Society, 23(3): 243 - 264. https://doi.org/10.1016/S0361-3682(97)00024-X

Chowdhury, A and Shil, N. C. (2016). Innovation in public sector management control systems in the context of new public management: a case of an Australian public sector organization. Journal of Entrepreneurship, Management and Innovation, 12(4): 99 - 126. https://ssrn.com/abstract=3105419

Crespo, N. F., Rodrigues, R., Samagaio, A., and Silva, G. M. (2019). The adoption of management control systems by start-ups: Internal factors and context as determinants. Journal of Business Research, 101: 875 - 884. https://doi.org/10.1016/j.jbusres.2018.11.020

Dekker, H.C., 2004. Control of inter-organizational relationships: evidence on appropriation concerns and coordination requirements. Accounting, Organizations and Society, 29 (1), 27-49. https://doi.org/10.1016/S0361-3682(02)00056-9 
Erben, J., Schneider, F. M., and Maier, M. (2019). In the ear of the beholder: self-other agreement in leadership communication and its relationship with subordinates' job satisfaction. International Journal of Business Communication, 56 (4): 505529. https://doi.org/10.1177/2329488416672431

Fisher, J. G. (1998). Contingency theory, management control systems and firm outcome: past results and future directions. Behavioral Research in Accounting, 10 (Supplement): $47-64$. https://www.search.proquest.com

Horngren, C. H., Datar, S. M. and Rajan, M. V. (2015). Cost Accounting: A Managerial Emphasis. Fifteenth edition. England: Pearson Education Limited. www.pearsonglobaleditions.com

Kelvin-Iloafu, L. E. (2016). The role of effective communication in strategic management of organizations. International Journal of Humanities and Social Science, 6 (12): 93 99. https://www.ijhssnet.com

Langfield-Smith, K. (1997) Management control systems and strategy: a critical review. Accounting, Organizations and Society, 22(2): 207 - 232. https://doi.org/10.1016/S0361-3682(95)00040-2

Luft, J. (2016). Cooperation and competition among employees: Experimental evidence on the role of management control systems. Management Accounting Research, 31: 75 - 85. https://doi.org/10.1016/j.mar.2016.02.006

Nguyen, T. T., Mia, L., Winata, L., and Chong, V. K. (2017). Effect of transformational-leadership style and management control system on managerial performance. Journal of Business Research, 70: 202 - 213. https://doi.org/10.1016/j.jbusres.2016.08.018

Nunnally, J. C. and Bernstein, I. H. (1994). Psychometric theory. 3rd Ed. New York: McGraw Hill, Inc. https://lccn.loc.gov/93022756

Pettit, J. D., Goris, J. R., and Vaught, B. C. (1997). An examination of organizational communication as a moderator of the relationship between job performance and job satisfaction. International Journal of Business Communication, 34 (1): 81-98. https://doi.org/10.1177/002194369703400105

Simons, R. (1995). Levers of control: how managers use innovative control systems to drive strategic renewal. First edition. Boston, Mass: Harvard Business School Press. http://id.lib.harvard.edu/alma/990051361020203941/catalog

Simons, R. (2014). Performance measurement and control systems for implementing strategy. First edition. England: Pearson Education Limited. www.pearsoned.co.uk

Smith, S. A., Patmos, A., and Pitts, M. J. (2018). Communication and teleworking: a study of communication channel satisfaction, personality, and job satisfaction for teleworking employees. International Journal of Business Communication, 55 (1): 44-68. https://doi.org/10.1177/2329488415589101

Zhang, X. (2014). Enterprise Management Control Systems in China. First edition. Germany: Springer Verlag Berlin Heidelberg. Library of congress control number: 2014939012. https://doi.org/10.1007/978-3-642-54715-7 


\section{Author's Biography}

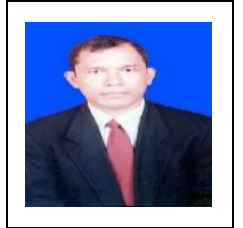

Muhammad Dahlan is a member of Accounting Department, Faculty of Business and Economics, Padjadjaran University, Bandung Indonesia. He earned a bachelor's degree in Accounting from University of Syiah Kuala in 1993, master's degree in Accounting from University of Kebangsaan Malaysia in 2006 and doctoral degree in Accounting from University of Padjadjaran in 2013. He has responsibilities to teach in subjects such as Management Accounting, Management Control System, and Management Strategic at Accounting Department. He has been worked at Public Accountant Firm, Private Company, and consultants. His research interest in management accounting systems, management strategic and policy, and performance measurement systems, throughout have been published in some reputable international journals. 